\title{
Picasso's Demoiselles
}




$$
\begin{aligned}
& \text { THE UNTOLD ORIGINS } \\
& \text { OF A MODERN MASTERPIECE }
\end{aligned}
$$

\section{Picasso's Demoiselles}

$$
\begin{aligned}
& n \\
& C \\
& N \\
& D \\
& z \\
& z \\
& m \\
& 0 \\
& 0 \\
& m \\
& n \\
& -1 \\
& 0 \\
& z \\
& 0 \\
& \square \\
& - \\
& m \\
& 0
\end{aligned}
$$

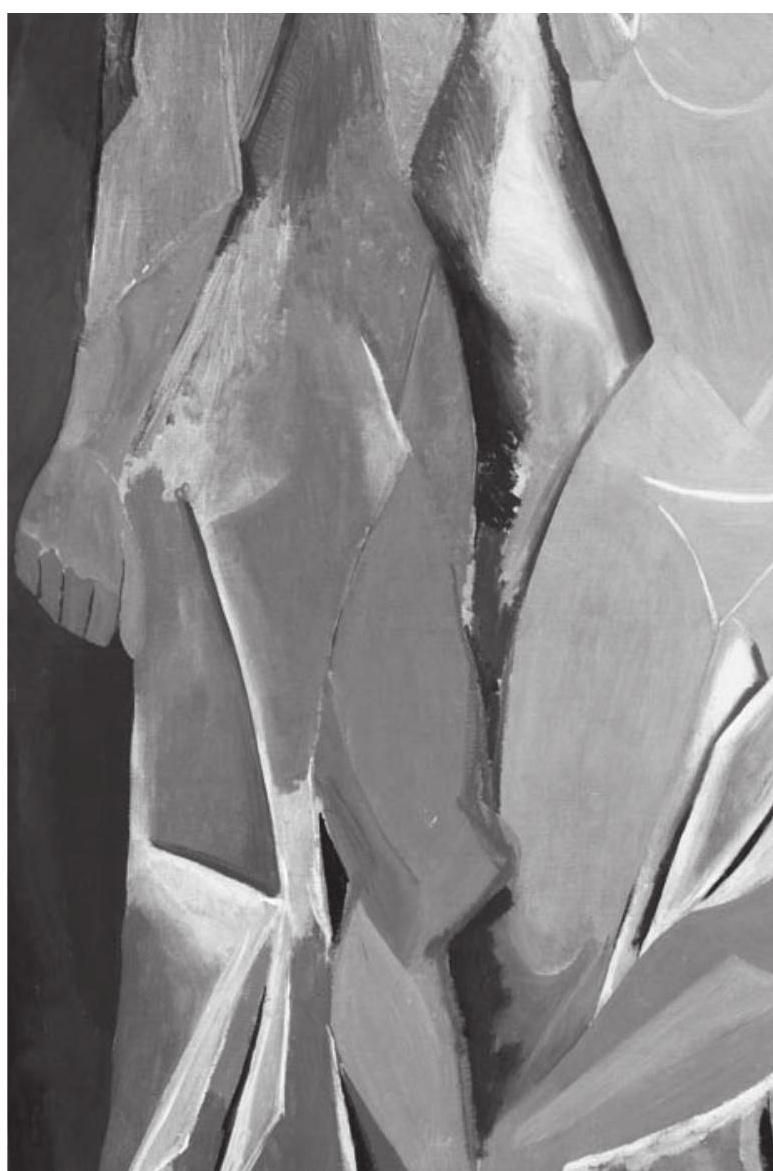




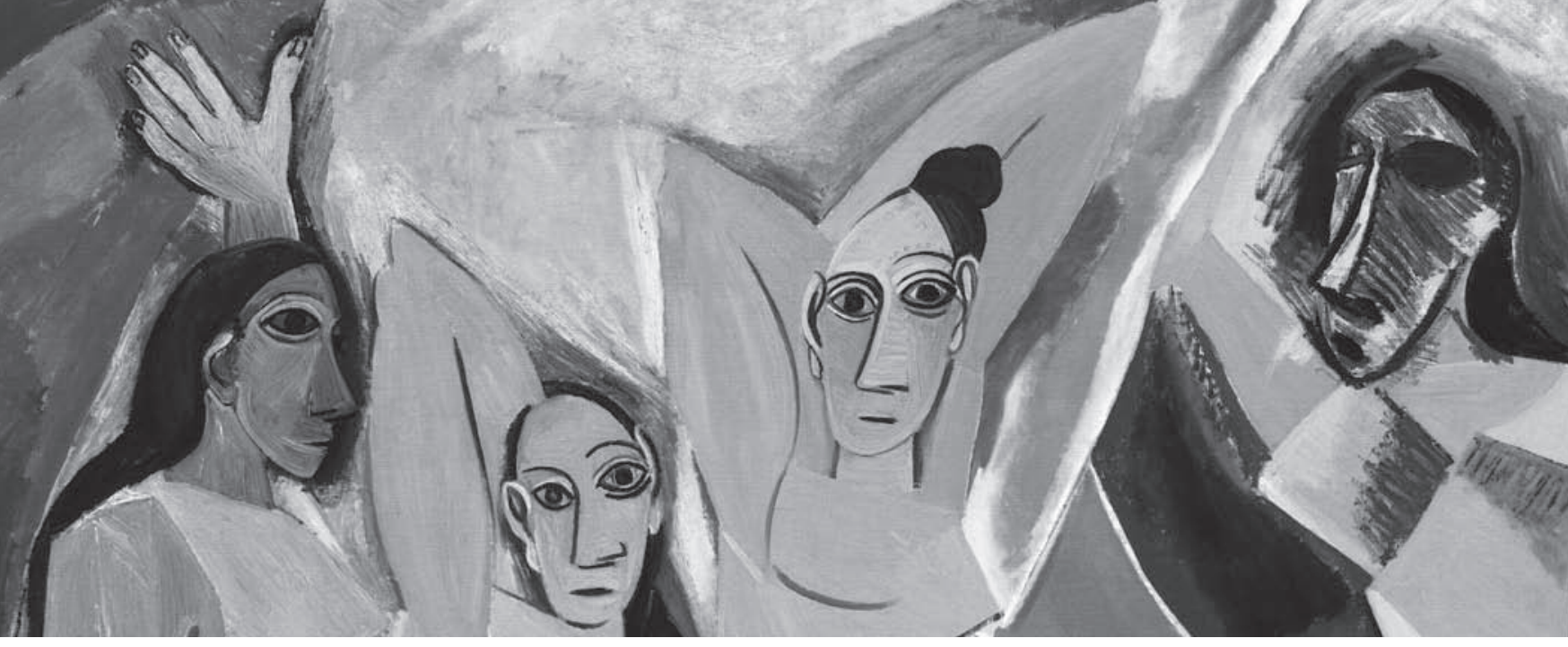

Duke University Press Durham and London 2019

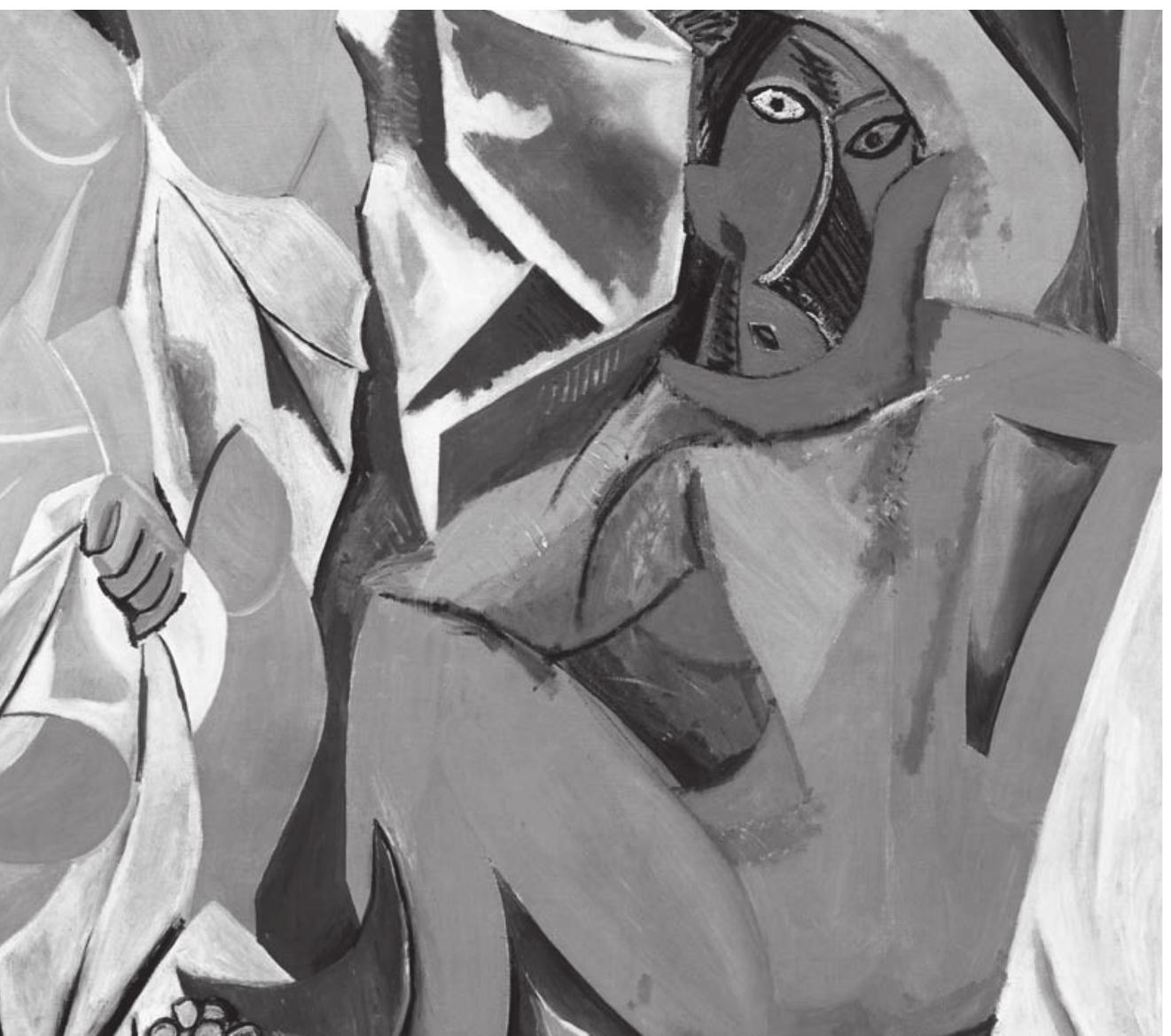


(C) 2019 Suzanne Preston Blier

All rights reserved

Printed in the United States of America on acid-free paper $\infty$

Cover designed by Drew Sisk.

Text designed by Mindy Basinger Hill.

Typeset in Garamond Premier Pro and The Sans by Bw \& A Books

Library of Congress Cataloging-in-Publication Data

Names: Blier, Suzanne Preston, author.

Title: Picasso's Demoiselles, the untold origins of a modern masterpiece /

Suzanne Preston Blier.

Description: Durham : Duke University Press, 2019. |

Includes bibliographical references and index.

Identifiers:

LCCN 2018047262 (print)

LCCN 2019005715 (ebook)

ISBN 978I 478002048 (ebook)

ISBN 978I47800005I (hardcover : alk. paper)

ISBN 978 I 478000198 (pbk. : alk. paper)

Subjects: LCSH: Picasso, Pablo, I88I-1973. Demoiselles d'Avignon. |

Picasso, Pablo, 1881-1973-Criticism and interpretation. | Women in art. |

Prostitution in art. | Cubism-France.

Classification: LCC ND553.P5 (ebook) | LCC ND553.P5 A635 2019 (print) |

DDC 759.4-dc23

LC record available at https://lccn.loc.gov/2018047262

Cover art: (top to bottom): Pablo Picasso, Les Demoiselles d'Avignon, detail, March 26, 1907. Museum of Modern Art, New York (Online Picasso Project) opp.07:001 | Anonymous artist, Adouma mask (Gabon), detail, before I820. Musée du quai Branly, Paris. Photograph by S. P. Blier, 2013 | Postcard of people in the Bamako market (Mali), detail, 1906. François-Edmond Fortier postcard. Types de Femmes series | Anonymous artists, Republic of the Congo and Gabon masks, detail, 19th century. Leo Frobenius, Die Masken und Geheimbünde Afrikas, I898, plate II. Illustrator: E. Hugelshofer.

Duke University Press gratefully acknowledges the generous support of the History of Art and Architecture Department, The Hutchins Center for African \& African American Research, and the Dean of Social Science at Harvard University, all of which provided funds toward the publication of this book. 


$$
\begin{aligned}
& 7 \\
& 0 \\
& 0 \\
& \swarrow \\
& 0 \\
& n \\
& m \\
& 5 \\
& < \\
& z
\end{aligned}
$$


This page intentionally left blank 